\title{
PENGALAMAN INJECTING DRUG USERS LIVING WITH HIVIAIDS (ILWHA) MENJALANI TERAPI ANTIRETROVIRAL SAAT TERAPI RUMATAN METADON
}

\author{
Fitria Handayani ${ }^{1,2^{*}}$, Dewi Irawaty ${ }^{3}$, Yati Afiyanti ${ }^{3}$ \\ 1. PSIK Fakultas Kedokteran Universitas Diponegoro, Semarang 50275, Indonesia \\ 2. Program Studi Magister Fakultas Ilmu Keperawatan Universitas Indonesia, Depok 16424, Indonesia \\ 3. Fakultas Ilmu Keperawatan Universitas Indonesia, Depok 16424, Indonesia \\ *Email:fitriaha@yahoo.co.id
}

\begin{abstract}
Abstrak
Penelitian merupakan penelitian kualitatif dengan pendekatan fenomenologi yang bertujuan memahami berbagai pengalaman Injecting Drug User Living with HIV/AIDS (ILWHA) dalam menjalani terapi antiretroviral (ARV) saat terapi rumatan metadon. Partisipan berjumlah 6 orang yang dipilih dengan purposive sampling. Pengumpulan data dengan wawancara mendalam dan analisis menggunakan metode "Colaizzi's". Penelitian menyimpulkan setiap ILWHA mengalami kebugaran dan lebih fungsional dalam hidup. Terdapat berbagai kebutuhan pelayanan kesehatan yaitu pelayanan yang terintegrasi antara ARV dan metadon, informasi penanggulangan efek ARV dan gizi serta informasi HIV, ARV dan metadon bagi masyarakat. Berdasarkan hal tersebut, perawat konselor ARV perlu memahami beban fisik, psikologis, dan sosial serta kedinamisan ILWHA dalam terapi ARV saat terapi rumatan metadon selain itu juga perlu mengidentifikasi dan mengembangkan lebih lanjut kebutuhan pelayanan kesehatan pada ILWHA.
\end{abstract}

Kata kunci: beban fisik, ILWHA, psikologi, sosial

\section{Abstract}

The research is qualitative research with phenomenology approach aimed at understanding the various experiences Injecting Drug Users Living with HIVIAIDS (ILWHA) in antiretroviral (ARV) therapy during methadone maintenance therapy. Participants totaled six people chosen by purposive sampling. Collecting data by in-depth interviews and analysis using the method "Colaizzi's". Research concluded were every ILWHA fitness experienced and more functional in life. There were a variety of health care needs of an integrated service between ARVs and methadone, information handling and nutrition and ARV effects of HIV information, ARV and metadon for the community. Based on this, nurses need to understand the burden of ARV counselor physical, psychological, and social development and dynamism ILWHA in ARV therapy during methadone maintenance therapy but it also needs to identify and develop further the need for health services in ILWHA.

Keywords: ILWHA, psychological burden, physical burden, social burden

\section{Pendahuluan}

Jumlah ILWHA (Injecting Drug Users Living with HIV/AIDS) 64\% dari jumlah pasien HIV/AIDS di Indonesia (Mesquita, et al., 2007). Berdasarkan hak azasi manusia, ILWHA tetap memiliki hak dalam memperoleh terapi ARV, walaupun dianggap sbagai seorang yang tidak produktif dan sebagai kriminal (Kahn, 2004). Menjalani terapi ARV bagi ILWHA berarti sebuah komitmen, tantangan dan kesempatan untuk berubah. Komitmen ILWHA berkaitan dengan manfaat maupun beban akibat ARV (Malta, Petersen, Claire, Freitas, \& Bastos, 2005; Kahn, 2004). Terapi ARV dapat meningkatkan kuali- tas hidup dan produktifitas ILWHA (Syamsuridzal \& Zubairi, 2003). ILWHA juga merasakan beban yang berkaitan dengan dosis. Beban yang dialami menimbulkan stress yang mengarah depresi. Beban yang dirasakan juga berasal dari interaksi antara ARV dan metadon, (Ellionore \& McCance-Katz, 2006; SK Menkes RI, 2006).

Program Terapi Rumatan Metadon merupakan program pemerintah untuk menurunkan dampak buruk penggunaan NAPZA (Depkes RI, 2007). Beban mental juga dialami ILWHA sebagai dampak jangka panjang penggunaan NAPZA. Stigma dan diskriminasi memberi beban psikologi bagi ILWHA. 
ILWHA dikucilkan dari pergaulan, dianggap sebagai kriminal dan bahkan dibunuh (KPA, 2008; UNAIDS, 2005). Depresi yang diakibatkan stres berhubungan dengan ketidakpatuhan terhadap terapi ARV (Patel \& Grimes, 2006). Ketidakpatuhan klien HIV/AIDS terhadap terapi ARV dapat menimbulkan menurunnya kemampuan ARV dalam mengendalikan virus yang dapat menimbulkan infeksi oportunistik pada klien (Paterson, et al., 2000). Perawat konselor ARV harus dapat menggali aspek-aspek yang berkaitan dengan hambatan yang mungkin akan dialami ILWHA saat terapi ARV (FHI, Impact, \& USAIDS, 2005). Pengalaman ILWHA yang menjalani terapi ARV saat terapi rumatan metadon perlu digali agar beban hidup dan permasalahan dapat teridentifikasi. Tujuan penelitian mengetahui pengalaman ILWHA dalam menjalani terapi ARV saat terapi rumatan metadon.

\section{Metode}

Penelitian ini mempelajari pengalaman ILWHA menjalani terapi ARV saat terapi rumatan metadon. Desain penelitian yaitu fenomenologi karena menggambarkan dan memberikan arti pada pengalaman hidup (Leininger, 1985; Munhall, 1989; Silvia \& Rothbart, 1984, dalam Burns \& Grove, 1999). Partisipan dipilih dengan menggunakan teknik Purposive Sampling dengan jumlah 6 ILWHA. Pengumpulan data dilakukan melalui wawancara mendalam (Indepth Interview). Wawancara dilakukan agar peneliti mendapatkan keluasan data (Denzin \& Lincoln, 1998, dalam Streubert \& Carpentes, 1999). Analisis data dilakukan dengan metode "Collaizi”. Hak partisipan selama proses penelitian dijaga dengan memperhatikan 5 hak yaitu selfdetermination, privacy, dignity, dan confidentiality, penanganan yang adil dan hak mendapatkan perlindungan atas ketidaknyamanan dan kerugian (ANA, 1985 dalam Macnee, 2004). Salah satu pendekatan untuk memenuhi 5 hak itu adalah inform consent.

\section{Hasil}

Usia partisipan 27-35 tahun. Pekerjaan partisipan yaitu seorang karyawan, dua orang wiraswasta, seorang bergerak di bidang jasa, dan seorang tidak bekerja. Ketika diwawancarai, semua (lima) partisipan telah menjalani terapi ARV lebih dari tiga bulan dan seorang partisipan menjalani ARV genap tiga bulan. Seorang partisipan menceritakan dirinya telah mengalami drop out setahun yang lalu selama empat bulan, dan setahun yang lalu juga partisipan tersebut memulai kembali terapi ARV.

Kombinasi ARV yang digunakan partisipan adalah dua orang partisipan menjalani terapi neviral (neviraphine) dan duviral (zidovudine dan lamivudine), seorang partisipan staviral (stavudine), dan efavirens, seorang partisipan neviral dan efavirens dan dua orang partisipan neviral, duviral, dan efavirens. Terapi rumatan metadon telah dijalani lima orang partisipan selama satu hingga dua tahun, sedangkan seorang partisipan telah mengikuti terapi rumatan metadon selama lima tahun.

Hasil wawancara lain diketahui bahwa seorang partisipan menjalani terapi ARV terlebih dahulu sebelum mengikuti terapi rumatan metadon dan sebaliknya. Semua partisipan memperoleh ARV di RSKO, sedang mendapatkan konseling ARV, seorang partisipan mengkuti konseling di RSKO dan Pokdisus dan lima orang mengikuti konseling di RSKO saja. Tema dalam penelitian ini ada 4 (empat) yaitu:

\section{Manfaat Menjalani Terapi ARV saat Terapi Metadon}

Partisipan merasakan manfaat ARV pada hilangnya kehitaman yang terjadi sebelum terapi ARV dan partisipan juga merasa lebih bugar sehingga fungsional.

"Terus kulit saya pada hitam saya garuk. Ternyata CD4 sudah dibawah 50. saya cek 2 kali masih rendah juga.... Saya konsul dokter I, saya dianjurin pake ARV Saya konsul ke dokter kulit. Terus nggak ada lagi.. Setelah satu bulan lah...”

“.. ARV badan jadi segar...otomatis PD... ga ketakutan... sebentar lagi aku sakit... sekarang udah berkurang... jadi lebih fungsional... baik untuk diri sendiri... jadi ingat makan teratur. tidur teratur.. ngurus anak... bersikap... ga meledak-ledak... emosional..." 


\section{Menjalani Terapi ARV Saat Terapi Rumatan Metadon, ILWHA Mengalami Berbagai Beban}

Beban fisik yang mereka alami adalah mual dan muntah serta gatal dan kemarahan pada kulit, kesakitan akibat gejala putus obat.

“...dimulai terapi ARV, dan mulainya pun banyak keluar infeksi, kaya... steven johnson, pas nuviral dan duviral itu... Mualnya...kadang mualnya apa nggak cocok?..."

“...Panas... seperti kayak sakau... ada angin bertiup kedinginan... kalau angin udah nggak ada... nggak dingin lagi...ntar kepanasan... ntar kedinginan, tulang terasa cape... kaya pegel... terutama kaki dari pangkal paha... sampai betis... pegel.. ngilu2.. Kuat untuk jalan... Cuma awal bangun tidur... berat banget... sampai sekarang masih. Pas sejak ARV dan metadon ini memang tidur juga terganggu..."

Beban psikologis yang dialami partisipan adalah ketidakberdayaan karena keinginan menurunkan dosis metadon dan ketidakmungkinannya karena dosis tinggi merupakan kebutuhan badan. Kecemasan juga dialami akibat terapi ARV yang mengharuskan partisipan untuk meminum ARV setiap hari dan seumur hidup dan kecemasan timbulnya sakau ketika akan minum ARV.

“..saya sih penginnya satu itu sajalah cukup.. ARV saja kalau bisa gitu.. kendalanya, kalau saya turun dosis saya turun ngak bisa.. melintir deh saya, nggak bisa...sakit badan saya... nggak bisa..."

“....Ada sih... sampai kapan obat ini? Kenapa saya harus terus-terusan kaya begini? Tapi saya berfikir lagi, kalau saya nggak minum obat, risikonya lebih besar..mungkin saya bisa jatuh sakit lagi... (menunduk, intonasi melamah)"

“....Waktu pertama takut... kebayang-bayang kalau mau pake ARV..... kebayang sakaunya....”

Gangguan mood setelah menggunakan efavirens, dan keinginan untuk kembali menggunakan NAPZA juga dialami partisipan.

“..Duviral, nggak. efevirens.. kacau.. deh.. perut panas... pusing.. kliyengan.. bikin mood ngaco... misalnya lagi ketawa-ketawa, minum efevirens, terus ketawa terus... ga berhenti-berhenti, pada-hal sudah selesai apa yang dilihat... tapi kalau mood turun... melihat yang kesel, kesel..."

“...Ga kenapa apa aja.. pingin mabok aja.. (menjawab dengan relax). Itu dia nggak ngerti... katanya pecandu ada rasa pingin aja... suggest aja... saya rasa Cuma itu... kebetulan ga ada masalah berat... pengin tahu aja... lama ngak pake... inget rasanya dulu... nongkrong $2 . . . "$

Beban sosial yang dialami partisipan adalah stigma, diskriminasi dan kehilangan kesempatan bekerja.

“..Kalau bagi saya.. sindiran dari orang lain... kalau mereka nggak ngerti... yang HIV atau apa, mungkin... jijik ngeliat saya tuh, dalam arti takut ketularan atau apa... padahal nggak segampang itu ter-tular...hanya dengan cara-cara tertentu aja...bagi mereka yang nggak tahu,, ngelihat saya jijik gitu loh... menganggap saya sampahlah gitu... dan yah... udah nggak dianggap manusia... saya nggak punya temen diluar... apa nanti saya diomongin mereka.. saya cuek aja jadinya... terserahlah..."

“...Kalau ngelamar kerja sewaktu-waktu ada tes kesehatan, otomatis kalau saya ketahuan positip, saya pasti nggak diterima kerja diinstansi, atau dikantor gitu..."

\section{Menjalani HIV/AIDS}

Menjalani terapi ARV pada saat terapi rumatan metadon merupakan suatu proses pembelajaran dan dilakukan dengan kepasrahan. Partisipan menjalani terapi ARV saat terapi rumatan metadon menganggap sebagai suatu proses pembelajaran, yaitu partisipan harus berfikir berulang kali untuk memutuskan mengikuti terapi tersebut. ILWHA juga menjalani dengan penuh kepasrahan karena memang terapi itulah yang harus dijalani risiko.

“...Kalau aku berfikir ya... pembelajaran... suatu kesalahan yang kita nggak bisa mundur... Kita harus berfikir berkali-kali untuk memulai segala sesuatu.... Seperti di ARV kita harus komitmen, kalau itu seumur hidup. Dan metadon juga sebagai komitmen..."

“...Aku nggak banyak berfikir sih.. yang penting aku jalanin aja.. Itu adalah sesuatu yang mutlak. itu adalah proses dengan sengirinya... andai kata aku memang siap..." 


\section{Berbagai Kebutuhan Pelayanan Kesehatan yang Dibutuhkan Partisipan saat Menjalani Terapi ARV pada saat Terapi Metadon}

Pelayanan kesehatan yang dibutuhkan berkisar tentang pelayanan yang terintegrasi untuk menanggulangi efek dari ARV dan metadon. Informasi tentang penanggulangan efek samping saat menjalani terapi ARV pada saat terapi rumatan metadon, serta informasi gizi.

“....Ya... yang bersamaan. Kadang-kadang kita harus di rever, untuk pelayanan ARV-nya, kita harus kesana jadi nggak ada, dari rumah sakit sini pun kadang-kadang kurang... kurang pengetahuan ARV juga kurang..."

“...Mungkin pengetahuan efek samping dari ARV dikasih tahu lebih banyak... dulunya dari dokter aja... tahunya melepuh, mual... yang penting adalah penanggulangan kalau terjadi efek samping..."

"Bisa masuk... susu bisa masuk... tapi harus encer... susu low fat saya ada HCV juga...HCV lebih lagi...jadi pertanyaan bisa terjawab... selama ini... masalah gizi... apa sih yang ga oleh... Cuma makanan sehat aja... ga puas..."

“...Penyuluhan-penyuluhan HIV diperbanyak. Untuk orang-orang tua yang anaknya ikut ARV dan metadon, terus selebaran-selebaran orang-orang diluar, biar mereka mengenal kita, nggak remeh.. terus cara penularan, obat-obatan, risi-ko yang menyebabkan kita terjangkit HIV..."

\section{Pembahasan}

Partisipan mengalami kehitaman pada kulit sebelum menjalani terapi ARV. Kehitaman tersebut sangat gatal. Menurut Almenji, Mbaugbaw, dan Nkam (2006), yang menyatakan bahwa tanda klinis dari AIDS adalah kandidiasis dan infeksi pernafasan. Menjalani terapi ARV pada ILWHA bermanfaat untuk menghilangkan kandidiasis dan batuk. Infeksi oportunistik dapat hilang sejalan dengan meningkatnya nilai CD4 dan menurunnya viral load pada saat terapi ARV (Paterson, et al., 2000). Kebugaran yang dirasakan oleh ILWHA sesuai dengan Wig, et al. (2007), HAART dapat meningkatkan kualitas hidup pengidap HIV/AIDS dalam jangka waktu yang lama dan adanya semangat menjalani kehidupan sehari-hari sehingga lebih fungsional. Rumatan metadon juga dapat meningkatkan kesehatan fisik dan psikologi (Micheil, 2007).

Beban fisik yang timbul setelah memulai terapi ARV adalah kemerahan dan gatal. Merah dan gatal adalah respon hipersensitivitas dari ARV yang ratarata terjadi pada minggu pertama hingga beberapa bulan (Kong \& Myers, 2005). ILWHA juga merasakan mual setelah minum ARV di pagi hari sehingga tidak bisa makan makanan padat di pagi hari. Mual merupakan efek samping dari ARV, namun mual juga merupakan tanda dan gejala putus obat (WHO, 2003). Gejala-gejala putus obat yang dirasakan partisipan adalah keringat dingin, sakit kepala, rinorea, lakrimasi, batuk, influenza, tulang terasa ngilu, telapak tangan terasa dingin, lemah, letih lesu, tidak bisa tidur pulas (Depkes RI, 2007). Gejala putus obat membuat ILWHA sangat membutuhkan metadon. Inetraksi ARV dan metadon dapat menurunkan kadar metadon plasma hingga 50\% (Depkes RI, 2007).

Gejala putus obat harus diwaspadai oleh perawat konselor ARV karena dapat menjadi alasan bagi ILWHA untuk drop out dari terapi ARV dan juga memicu penggunaan heroin kembali. Komunikasi yang terbuka antara ILWHA dan petugas kesehatan sangat diperlukan (WHO, 2003). Mual yang dirasakan ILWHA disebabkan efek ARV dan gejala putus obat. Perawat konselor ARV dan perawat di program rumatan metadon perlu memantau pola makan ILWHA, karena berhubungan dengan farmakokinetik yang dapat menurunkan supresi viral load dan dapat meningkatkan resistensi ARV (Paterson, et al., 2000; WHO, 2003).

Pada ILWHA, beban psikologi sama beratnya dengan beban fisik dan lebih komplek dari pasien HIV/AIDS. Tanda-tanda ketidakberdayaan dan isolasi ILWHA harus diperhatikan, karena akan mengarah pada depresi dan kecemasan (Stefna, 2007). ILWHA tidak berdaya untuk menurunkan dosis metadon karena dosis yang tinggi merupakan kebutuhan menghilangkan gejala putus obat. Ketidakberdayaan dapat menimbulkan depresi (Abramsom, Metalsky, \& Alloy, 1989, dalam Dowd, 2004). 
ILWHA cemas terhadap lamanya penggunaan ARV. Menurut Miner dan Dowd (1996, dalam Dowd, 2004) menjelaskan bahwa kecemasan salah satunya ditandai dengan ketakutan. Gangguan mood yang akibat efek efavirens berkisar dari depresi dan euforia (Wood, et al., 2006). Tanda dan gejala depresi berkaitan dengan proses biologi dari sistem imun, yaitu jumlah CD4. Masalah depresi juga berpengaruh pada perilaku sehat yang mendukung kepatuhan terhadap terapi ARV (Lima, 2007).

Keinginan menggunakan NAPZA kembali dialami oleh ILWHA. NAPZA diluar metadon dapat menimbulkan overdosis (Vlahov, et al., 2007). Penggunaan NAPZA diluar metadon dikarenakan berpergian bersama dengan teman yang masih menggunakan NAPZA, mengobati gejala putus obat, berhenti dari terapi metadon, dan interaksi antara terapi HIV termasuk ARV dengan metadon. Namun, Vlahov mengemukakan bahwa meskipun pengobatan HIV menurunkan intensitas metadon, namun tidak ada hubungan antara penggunaan NAPZA diluar metadon dengan status tatalaksanan pada HIV serta penularan HIV. Penelitian Vlahov menyimpulkan antara terapi ARV dan metadon bukan faktor yang utama pada ILWHA untuk menggunaan NAPZA diluar terapi metadon.

ILWHA tidak memiliki teman pergaulan, dan masyarakat mengangap jijik. Diskriminasi yang dihadapi pengidap HIV/AIDS muncul dalam berbagai bentuk, dari yang hampir tak tampak sampai kekerasan fisik (Murni, 2003). Stigma berhubungan dengan kesakitan, infeksius, dan kerusakan sebagian angota tubuh atau kematian, walaupun masyarakat telah diberi informasi (Varas-Diaz \& ToroAlfonso, 2003). Julukan sebagai kriminal melekat pada IDU sejak berlakunya undang-undang narkotik (Kahn, 2004). Pengidap HIV/AIDS mengalami peningkatan produktifitas setelah era HAART (Goldman \& Bao, 2004). Namun ILWHA tetap tidak mendapatkan pekerjaan karena berhubungan dengan perilaku mereka saat sebagai IDU. Kesempatan bekerja padahal berpengaruh bagi kesuksesan ILWHA untuk mengikuti program terapi rumatan metadon (Micheil, 2007).
Perawat konselor ARV harus memfasilitasi proses pembelajaran (FHI, Impact, \& USAIDS, 2005). Makna yang lain adalah kepasrahan. Terdapat kaitan dalam ketidakberdayaan, kepasrahan dan harapan. Perawat konselor ARV harus mengkonstruksikan harapan dalam ketidakberdayaan dan kepasrahan ILWHA dalam terapi ARV dan metadon (Kylma, Vehvilainen-Julkunen, \& Lahdevirta, 2001;Depkes, 2007). ILWHA membutuhkan pelayanan yang terintegrasi antara pelayanan ARV dan metadon yang diselenggarakan dalam “One Stop Shopping” yang dapat memberikan layanan terjadi gangguan kesehatan dalam waktu yang bersamaan (WHO, 2003). ILWHA membutuhkan informasi penanggulangan efek ARV, namun penjelasan tersebut belum menjadi SOP pada terapi ARV (FHI, Impact, \& USAIDS, 2005). ILWHA membutuhkan informasi tentang layanan gizi untuk menjaga stamina (WHO, 2003). Menurut ILWHA, bahwa masyarakat juga harus diberi informasi mengenai HIV, ARV dan metadon untuk menurunkan stigma. Informasi tersebut juga sebagai usaha harm reduction (Mesquita, et al., 2007).

\section{Kesimpulan}

ILWHA dalam menjalani terapi ARV pada saat terapi rumatan metadon, merasakan manfaat yaitu meningkatkan daya tahan dan membawa kebugaran yang meningkatkan fungsional hidup ILWHA. Beban fisik yang muncul adalah mual dan gejala putus obat diakibatkan efek ARV, gejala putus obat akibat interaksi ARV. Beban psikologi adalah ketidakberdayaan, kecemasan, dan gangguan mood dan keinginan kembali menggunakan NAPZA. Beban sosial adalah stigma dan diskriminasi serta kehilangan kesempatan bekerja.

Makna menjalani terapi ialah proses pembelajaran dan kepasrahan menjalaninya. ILWHA membutuhkan pelayanan yang terintegrasi antara terapi ARV dan terapi rumatan metadon, dan ILWHA membutuhkan informasi mengenai efek samping ARV dan gizi. ILWHA juga menginginkan informasi HIV, ARV, dan metadon bagi masyarakat luas sebagai perlindungan masyarakat sendiri dan untuk mengurangi stigma masyarakat terhadap ILWHA. 
Perawat konselor ARV harus memahami beban fisik, psikologis, dan sosial ILWHA dalam menjalani terapi ARV saat terapi rumatan metadon, agar intervensi diberikan tepat. Perawat juga harus mengkonstruksikan harapan di antara ketidakberdayaan dan kepasrahan. Penanggulangan efek ARV perlu diberi pada ILWHA sebagai SOP saat memulai terapi. Informasi tentang HIV, ARV, dan metadon perlu diberi pada masyarakat untuk mengurangi stigma dan dampak buruk NAPZA (SS, ENT, RR).

\section{Referensi}

Almenji, M., Mbaugbaw, J., \& Nkam, M. (2006). Association between CD4 celland clinical presentation among HIV/AIDS patients in Cameroon. $J$ Med Sci, 6 (5), 843 - 847.

Goldman, D.P., \& Bao, Y. (2004). Effective HIV treatment and the employment of HIV+ adults. Health Serv Res, 39 (6 Pt 1), 1691-1712.

Depkes, RI. (2007). Panduan Program Terapi Rumatan Metadon. Jakarta: Departemen Kesehatan Republik Indonesia.

Varas-Diaz, N., \& Toro-Alfonso, J. (2003). Incarnating stigma: visual images of the body with HIV/AIDS. Forum Qualitative Social Research, 4 (3). Diperoleh dari http://www.qualitative research.net/

Ellionore, F., \& McCance-Katz. (2006). Antiretroviral therapy in injection drug users with HIV diseaseusing drug interactions to design more effective treatment. Diperoleh dari http://www.ucsf.edu/

FHI, Impact, \& USAIDS. (2005). Standard operating procedure for antiretroviral therapy. Diperoleh dari http://www.fhi.org/.

Kahn, P. (2004). AIDS vaccine handbook: Global perspectives (2rd Ed.). New York: AIDS Vaccine Advocacy Coalition.

Kong, H.H., \& Myers, S.A. (2005). Cutaneous effects of highly active antiretroviral therapy in HIVinfected patients. Dermatol Ther, 18 (1), 58 - 66.

Kylma, J., Vehvilainen-Julkunen, K., \& Lahdevirta, J. (2001). Hope, despair, and hopelessness in living with HIV/AIDS: A grounded theory study. $J A d v$ Nurs, 33 (6), 764-75.

Lima. (2007). Depression can be fatal for those on HIV drug regimens. Diperoleh dari www.cfenet.ubc.

Macnee, C.L. (2004). Understanding nursing research: Reading and using research in practice. Philadelphia: Lippincott, William and Wilkins.
Malta, M., Petersen, M.L., Claire, S., Freitas, F., \& Bastos, S.I. (2005). Adherence to antiretroviral therapy: a qualitative study with physicians from Rio de Janeiro, Brazil. Cadernos de Saúde Pública, 21 (5), 1424-1432.

SK Menkes, RI. (2006). Keputusan menteri kesehatan Republik Indonesia NOMOR 494/MENKES/SK/ VII/2006. Diperoleh dari http://www.kpa.org.

Mesquita, F., Winarso, I., Atmosukarto, I.I, Eka, B., Nevendorff, L., Rahmah, A. . . Angela, R. (2007). Public health the leading force of the Indonesian response to the HIV/AIDS crisis among people who inject drugs. Harm Reduction Journal, 4 (9).

Murni, S. (2003). Hidup dengan HIV/AIDS. Jakarta: Yayasan Spiritia.

Paterson, D.L., et al. (2000). Adherence to protease inhibitor therapy and outcomes in patients with HIV infection. Diperoleh dari http://www.scielo.br/ $\mathrm{pdf} / \mathrm{csp} / \mathrm{v} 22 \mathrm{n} 4 / 02$.pdf.

Paterson, D.L., Swindells, S., Mohr, J., Brester, M., Vergis, E.N., Squier, C., Wagener, M.M., \& Singh, N. (2000). Adherence to protease inhibitor therapy and outcomes in patients with HIV infection. Ann Intern Med, 133 (1), 21 - 30.

Patel, P.N., \& Grimes, R.M. (2006). Symptom exacerbation and adherence to antiretroviral therapy during the menstrual cycle: A pilot study. Infect Dis Obstet Gynecol, 2006, 14869.

Streubert, H.J., \& Carpenter, D.R. (1999). Qualitative research in nursing: advancint the humanistic imperative (2nd ed.). Philadelphia: Lippincott, William \& Wilkins.

Syamsuridzal, \& Zubairi. (2003). Pelaksanaan infeksi HIV di pelayanan kesehatan dasar. Jakarta: Balai Penerbit FK UI.

Vlahov, D., O’Driscoll, P., Mehta, S.H. Ompad, D.C., Gern, R., Galai, N., \& Kirk, G.D. (2007). Risk factors for methadone outside treatment programs: Implications for HIV treatment among injection drug users. Addiction, 102 (5), 771 - 777.

Wig, N., Lekshmi, R., Pal, H., Ahuja, V., Mittal, C.M., \& Agarwal, S.K. (2006). The impact of HIV/AIDS on the quality of life: A cross sectional study in north India. Indian J Med Sci, 60, 3-12.

Wood, E., Hogg, R.S., Kerr, T., Bonner, S., Strathdee, S.A., Palepu, A., \& Montaner, J.S.G. (2007). Rates of inappropriate antiretroviral prescription among injection drug users. Harm Reduct J, 4 (2).

WHO. (2003). European framework to decrease the burden of $T B / H I V$. Diperoleh dari www.who.int. 